\title{
Respiration Rate, Ethylene Production, and Cellular Leakage of Fig Fruit following Vibrational Stress
}

\author{
Linchun Mao, Tiejin Ying, Yufang Xi, and Yonghua Zhen \\ Department of Food Science, Zhejiang Agricultural University, Hangzhou \\ 310029, People's Republic of China
}

Additional index words. Ficus carica, $\mathrm{CO}_{2}$ production

Fig (Ficus carica L.) is one of the most perishable climacteric fruit (Marie and Crane, 1971). To obtain optimum flavor, fig fruit should be harvested when almost fully ripe. However, at this stage, it is soft and susceptible to deterioration (Pantastico, 1975), limiting postharvest life to 7 to 14 days under refrigeration (Tsantili, 1990).

Mechanical stress (vibration, impact, and compression) during transport can lead to physical damage and loss of quality (Chuma et al., 1967; Lidster and Tung, 1979; Ogawa et al., 1972). However, we found no information on commodity physiological response to vibrational stress at accelerations insufficient to produce direct injury. We, therefore, investigated the effect of vibration on respiration rate, ethylene production, and cellular leakage of three fig cultivars.

'Masui dauphine', 'Celeste', and 'Brunswick' figs growing in Hangzhou were harvested at commercial maturity (7 Sept. 1993), as evaluated by skin color and firmness. Fruit were gently transported to the laboratory within $3 \mathrm{~h}$ of harvest and stored overnight $(15 \mathrm{~h})$ at $0 \mathrm{C}$. On the next day, fruit were removed from cold storage and placed in open plastic bags to equilibrate with the room temperature $(26 \mathrm{C})$. Fruit $(1 \mathrm{~kg})$ were placed in plastic containers and held in place with cotton wool. The containers were attached to a vertical vibrator (55-mm stroke) and vibrated for $10 \mathrm{~min}$ at accelerations of $1 \times, 2 \times, 3 \times, 4 \times, 5 \times$, and $6 \times g$, respectively. Triplicate fruit samples of each cultivar were used for the vibration treatments and the corresponding determinations of respiration rate, ethylene production, and cellular leakage.

Respiration rate was monitored with an infrared $\mathrm{CO}_{2}$ analyzer at an air flow of 500 $\mathrm{ml} \cdot \mathrm{min}^{-1}$ during vibration of four fruit at $26 \mathrm{C}$. Ethylene production was determined by placing fruit in a $380-\mathrm{ml}$ glass jar at $26 \mathrm{C}$ for $3 \mathrm{~h}$ (including $10 \mathrm{~min}$ of vibration). Two $0.1-\mathrm{ml}$ headspace gas samples were analyzed by gas

Received for publication 2 June 1994. Accepted for publication 30 July 1994. Project supported by the Natural Science Foundation of China. The cost of publishing this paper was defrayed in part by the payment of page charges. Under postal regulations, this paper therefore must be hereby marked advertisement solely to indicate this fact. chromatography with an $\mathrm{H}_{2}$-flame ionization detector and a stainless steel GDX-502 (Tianjin Chemical Reagent Plant, Tianjin, China) column at 70C.

Electrolyte leakage from tissue slices was measured as relative conductivity. After vibration, fruit were cut into 3 -mm-thick slices, and pieces $(5 \times 8 \mathrm{~mm})$ were subsequently removed from slices with a razor blade and mixed. A portion $(500 \mathrm{mg})$, taken randomly, was washed three times with $5 \mathrm{ml}$ distilled water and placed in a 50-ml beaker with $40 \mathrm{ml}$ distilled water. The conductivity of the bathing solution was determined at the beginning $\left(\mathrm{C}_{0}\right)$ and after being stirred for $30 \mathrm{~min}\left(\mathrm{C}_{30}\right)$ at $26 \mathrm{C}$. The relative conductivity $\left(\mu \mathrm{S} \cdot \mathrm{kg}^{-1} \cdot \mathrm{min}^{-1}\right)$ was calculated as $\left(\mathrm{C}_{30}-\mathrm{C}_{0}\right) / \mathrm{C}_{0} / \mathrm{wt} / 30$.

Carbon dioxide production increased linearly with vibration in all cultivars tested (Fig. 1A). 'Masui dauphine' generated more $\mathrm{CO}_{2}$ than 'Celeste' or 'Brunswick' at each vibrational acceleration. 'Masui dauphine' respiration rate increased at a significantly higher rate than that of the other cultivars, suggesting a greater response to vibration.

There was a significant correlation between ethylene production and degree of vibration (Fig. 1B). 'Masui dauphine' had the greatest increase of ethylene production per unit increase in vibration.

Cellular leakage increased with increasing vibration above $2 \times g$ (Fig. $1 C$ ). Leakage was higher at $1 \times g$ than at 0 or $2 \times g$ (Fig. 1C). This result was similar to that for respiration of tomato (Lycopersicon esculentum Mill.) fruit (Nakamura and Ito, 1976). The increase in cellular leakage suggests that there was a loss of membrane integrity. 'Masui dauphine' had a higher rate of leakage than the other two cultivars over most of the range of vibrational force. The higher rates of respiration and ethylene production and the increased cellular leakage of 'Masui dauphine' indicate that it is susceptible to vibrational stress and, possibly, more susceptible to deterioration during transportation and storage.

Although fruit exposed up to $6 \times g$ did not show any visible damage when the fruit were properly immobilized in the container, careful management to avoid vibrational stress during postharvest handling, especially during transportation, is important to maintain fresh fig fruit in sound condition.
Chuma, Y., S. Murata, T. Abe, and I. Hayakwa. 1967. Investigation on in-transit injury of farm products. Vibrating characteristics and injury of pears in carton box. J. Soc. Agr. Machinery, Jpn. 29(2):82-87.

Lidster, P.D. and M.A. Tung. 1979. Identification of deformation parameters and fruit response to mechanical damage in sweet cherry. J. Amer. Soc. Hort. Sci. 104:808-814.

Marei, N. and J.C. Crane. 1971. Growth and respiratory response of fig fruits to ethylene. Plant Physiol. 48:249-254.

Nakamura, R. and T. Ito. 1976. The effects of vibration on the respiration of fruit. 1. Changes in the respiration rate of tomato fruit during and after vibration. J. Jpn. Soc. Hort. Sci. 45(3):313319.

Ogawa, J.M., E. Bose, B.T. Manji, and W.R. Schraeder. 1972. Bruising of sweet cherries resulting in internal browning and increased susceptibility to fungi. Phytopathology 72:579580.

Pantastico, E.B. (ed.). 1975. Postharvest physiology, handling and utilization of tropical and subtropical fruits and vegetables. AVI, Westport, Conn.

Tsantili, E. 1990. Changes during development of 'Tsapela' fig fruits. Scientia Hort. 44:227-234.

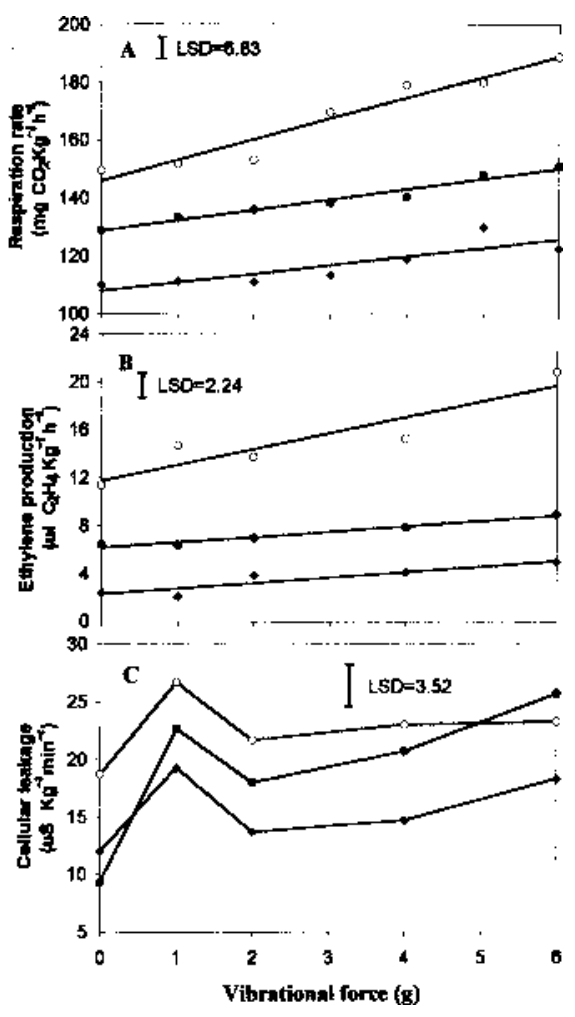

Fig. 1. Effect of vibrational force on (A) respiration rate, $(\mathbf{B})$ ethylene production, and $(\mathbf{C})$ cellular leakage for (O) 'Masui dauphine', (@) 'Brunswick', and ( ) 'Celeste' figs. The vertical bar represents the LSD $(\alpha \leq 0.05)$. Regression models: A) 'Masui dauphine': $\mathrm{Y}=145.97+$ $7.14 \mathrm{x}, r=0.97$; 'Brunswick': $\mathrm{Y}=128.67+$ $3.57 \mathrm{x}, r=0.98$; 'Celeste': $\mathrm{Y}=107.97+2.94 \mathrm{x}$, $r=0.86$. B) 'Masui dauphine': $\mathrm{Y}=11.73+$ $1.33 \mathrm{x}, r=0.92$; 'Brunswick': $\mathrm{Y}=6.16+0.44 \mathrm{x}$, $r=0.98$; 'Celeste': $\mathrm{Y}=2.27+0.46 \mathrm{x}, r=0.92$. 